\title{
BENTUK PERLINDUNGAN HUKUM DAN TANGGUNG JAWAB BANK TERHADAP KERUGIAN PENGGUNA KARTU KREDIT AKIBAT KELALAIAN DALAM PENGAWASAN OLEH BANK
}

\author{
Annisa Medyana Akhiar \\ Mahasiswa Pasca Sarjana Fakultas Ilmu Hukum Universitas Indonesia
}

\begin{abstract}
Abstrak. Kartu kredit yang merupakan alat pembayaran yang sudah sangat terkenal dan banyak digunakan saat ini, masih mempunyai problema-problema yang perlu untuk diselesaikan. Terlebih lagi dengan perkembangan zaman, melakukan sebuah kegiatan perbuatan melawan hukum, khususnya dalam hal ini adalah kartu kredit bukanlah menjadi sebuah hal yang susah. Bank sebagai pihak yang mengeluarkan produk kartu kredit haruslah melakukan pengawasan dan peningkatan keamanan kartu kredit dari waktu ke waktu secara berkala. Konsumen sebagai nasabah dari pengguna kartu kredit tentunya jika terjadi perbuatan melawan hukum yang merugikan dirinya, tentu tidak akan diam. Bank selaku perusahaan haruslah dapat memberikan perlindungan dan rasa aman serta bertanggungjawab terhadap setiap kerugian yang ditimbulkan oleh perusahannya kepada konsumen, seperti yang diatur di dalam Undang-Undang No 8 Tahun 1999 tentang Perlindungan Konsumen dan Peraturan Otoritas Jasa Keuangan Nomor 1/POJK.07/2013 tentang Perlindungan Konsumen di Bidang Jasa Keuangan.
\end{abstract}

\section{Kata kunci : Tanggung Jawab Bank, Kartu Kredit, Perlindungan Konsumen}

\section{PENDAHULUAN}

Di era yang penuh digital ini, menuntut masyarakat berkembang mengikuti zaman. Bukan hanya masyarakat, kegiatan sehari-hari pun juga dituntut untuk berkembang, seperti halnya kegiatan bisnis, jual beli, melakukan pembayaran, bahkan saat ini untuk memesan sebuah makanan pun dapat dilakukan dengan sangat mudah. Bentuk dan jenis pembayaran pun saat ini bermacam ragam. Dulu, hanya mengenal pembayaran dengan uang tunai, dan pembayaran pun dilakukan face to face, kini pembayaran dapat dilakukan dengan mudah, dan tidak melulu harus face to face, dapat dilakukan dimana saja kapan saja dan oleh siapa saja. Salah satu bentuk pembayaran yang banyak digunakan oleh orang-orang pada masa kini adalah pembayaran menggunakan Kartu Kredit. Kartu kredit merupakan bentuk pembayaran yang dimana mempunyai prinsip pembayaran, beli sekarang bayar nanti, atau "buy now, pay later", yang artinya bahwa kewajiban pembayaran kartu kredit akan lebih dulu dibayarkan oleh pihak yang mengeluarkan kartu, lalu pemegang kartu baru melakukan kewajiban pembayaran pada waktu yang telah disepakati antara penerbit kartu dengan pemegang kartu. Kartu kredit merupakan alat pembayaran yang dikeluarkan oleh pihak perbankan, sebagai salah satu bentuk produk yang di tawarkan oleh pihak Bank kepada Nasabah pengguna Bank tersebut.

Tentunya dengan ada Kartu Kredit ini, masyarakat sangat dipermudah dalam melakukan transaksi, namun dengan adanya kartu kredit ini pula banyak menimbulkan permasalahan di masyarakat, mulai dari penipuan, pembobolan, hingga permasalahan terkait penagihan dari pihak bank ke konsumen dan kejahatan-kejahatan terkait kartu kredit lainnya. Kejahatan terkait kartu kredit sangat tergantung dengan kemajuan teknologi, mengapa? Karena dengan semakin maju teknologi maka kesempatan untuk melakukan kejahatan semakin tinggi. Saat ini, khususnya di Indonesia, kejahatan terkait kartu krsedit masih marak. Kasus terkait kejahatan kartu kredit dari tahun ke tahun selalu ada dan cenderung terjadinya peningkatan, walaupun peningkatan tersebut tidak signifikan, namun kejahatan terkait kartu kredit selalu terjadi setiap tahunnya.

Di Indonesia sendiri, Pengaturan mengenai kartu kredit ini diatur di dalam Undang-Undang Nomor 10 Tahun 1998 
tentang Perbankan sebagai peraturan utama atau payung hukum dalam melaksanakan kegiatan kartu kredit, selain itu

pengaturan terkait kartu kredit ini juga diatur di dalam Peraturan Bank Indonesia Nomor 14/2/PBI/2012 tentang Penyelenggaraan Kegiatan Alat Pembayaran Menggunakan Kartu. Tidak hanya Bank Indonesia saja, Otoritas Jasa Keuangan pun juga turut mengatur terkait pelaksanaan transaksi pengunaan kartu kredit ini, sebagaimana kita tahu, bahwa Bank Indonesia telah mengalihkan sebagian atau beberapa tugasnya kepada suatu lembaga yang saat ini dikenal dengan Otoritas Jasa Keuangan atau sering kali disingkat dengan istilah OJK. Bahwa kartu kredit merupakan salah satu bentuk kegiatan pembiayaan yang masuk ke dalam salah satu lembaga pembiayaan yang diatur dalam Pasal 1 angka 9 Undang-Undang Nomor 21 Tahun 2011 tentang Otoritas Jasa Keuangan. OJK sebagai lembaga yang berwenang turut serta mengatur mengenai kartu kredit, adapun peraturan terkait kartu kredit ini diatur di dalam Peraturan Otoritas Jasa Keuangan atau disingkat POJK Nomor 1/POJK.07/2013 tentang Perlindungan Konsumen Sektor Jasa Keuangan. OJK sebagai bentuk lembaga yang mengambil alih beberapa kewenangan Bank Indonesia (BI) dalam hal ini bekerja sama dengan BI, sehingga peraturan perundang-undangan di sektor keuangan masih tetap berlaku selama tidak bertentangan satu sama lain dan belum ada undang-undang pengganti. Namun, pelaksanaan terhadap peraturan-peraturan yang ada masih kurang, dan pelaksanaannya masih banyak diabaikan, bahkan masih banyak masyarakat yang tidak mengetahui peraturan terkait kartu kredit. Sedangkan masyarakat, khususnya nasabah pengguna kartu kredit merupakan konsumen yang harus dilindungi haknya dan harus mengetahui juga kewajibannya sebagai nasabah.

Bank sebagai pihak yang mengeluarkan kartu kredit, haruslah memberikan jaminan keamanan kepada nasabah, dan memberikan perlindungan yang cukup jika di kemudian hari terjadi kejahatan terhadap kartu kredit yang merugikan nasabah pengguna. Sebagai contoh kasus pembobolan kartu kredit yang di bobol hanya melalui sim card yang telah cukup lama tidak digunakan oleh pemilik, selain kasus ini, ada juga kasus pembobolan kartu kredit dan membuat nasabah bank rugi hingga 1,1 Milliar, belum lagi pegawai bank melakukan penagihan kartu kredit yang tidak sesuai aturan berlaku dan merugikan nasabah. Tentunya kasus-kasus diatas hanya segelintir contoh dari bagaimana lemahnya keamanan dan bagaimana lalainya bank dalam melindungi nasabah pengguna kartu kredit. Jika kasus-kasus seperti ini di biarkan secara terus-menerus dan tidak adanya penindakan seperti peningkatan keamanan dan memberikan perlindungan yang lebih kepada nasabah, maka akan dengan perlahan minat untuk menggunakan kartu kredit pun berkurang. Dalam hal ini, dipertanyakan bagaimana tanggung jawab Bank sebagai Lembaga yang mengeluarkan produk kartu kredit jika kasus-kasus diatas terjadi, tentunya sebelum meminta pertanggungjawaban bank, harus mengetahui terlebih dahulu hubungan seperti apa yang terikat antara bank dengan nasabah.

Metode penelitian yang akan digunakan adalah metode penelitian deskriptif-analitis, dengan menggunakan metode pendekatan yaitu yuridis-normatif, dimana yang menjadi sumber data primer adalah peraturan perundang-undangan dan untuk sumber data sekunder penulis akan menggunakan literaturliteratur yang terkait dengan penulisan ini. Dengan deskriptif-analitis dan pendekatan yuridis-normatif, penelitian in lebih menekankan kepada penelaahan lebih dalam atas ketentuan-ketentuan yang tertulis dalam sebuah peraturan perundang-undangan dan literatur-literaturr yang akan di analisis untuk menemukan jawaban atas permasalahan yang ada dibawah ini

\section{Rumusan Masalah}

1. Bagaimana hubungan nasabah khususnya nasabah pengguna kartu kredit dengan bank secara hukum?

2. Bagaimana bentuk tanggung jawab dan perlindungan hukum yang dapat diberikan oleh bank kepada nasabah pengguna kartu kredit?

KAJIAN PUSTAKA 


\section{A. Hubungan Nasabah Pengguna Kartu Kredit dengan Bank Secara Hukum}

Di dunia hukum perbankan, terdapat 4 (empat) prinsip yang harus di pegang teguh untuk menjalankan bisnis perbankan. Karena prinsip ini lah yang menjadi landasan utama calon nasabah untuk "menitipkan" uang miliknya kepada bank yang selanjutnya akan di kelola oleh bank, baik digunakan untuk pemberian kredit, maupun yang lainnya. Keempat prinsip ini adalah prinsip kepercayaan (fiduciary relation principle), prinsip kehati-hatian (prudential principle), prinsip kerahasiaan (secrecy principle), dan prinsip mengenal nasabah (know your costumer principle). Prinsip ini dituangkan ke dalam pasal-pasal pada Undang-Undang Perbankan baik secara implisit maupun eksplisit. Penjelasan terkait prinsip-prinsip perbankan ini adalah sebagai berikut :

1. Prinsip Kepercayaan (Fiduciary Relation Principle)

Prinsip kepercayaan adalah asas yang melandasi hubungan antara pihak bank dengan nasabah bank. Dalam hal ini, bank menjalankan usahanya dari dana masyarakat yang disimpan berdasarkan kepercayaan, sehingga setiap bank sangat perlu untuk menjaga kesehatan banknya dengan tetap memelihara dan mempertahankan kepercayaan masyarakat. Prinsip kepercayaan ini dalam Undang-Undang Perbankan Nomor 10 Tahun 1998 diatur dalam Pasal 29 ayat (4).

2. Prinsip kehati-hatian (Prudential principle)

Prinsip kehati-hatian ini adalah prinsip yang menegaskan bahwa bank dalam menjalankan setiap kegiatan usahanya, baik dalam penghimpunan maupun dalam penyaluran dana kepada masyarakat haruslah sangat berhati-hati. Tujuan dari prinsip kehati-hatian ini adalah agar bank selalu dalam keadaan sehat menjalankan setiap kegiatan usahanya dan mematuhi setiap ketentuan dan norma hukum yang berlaku di dunia perbankan. Prinsip kehati-hatian ini ada dalam Pasal 2 dan Pasal 29 ayat (2) UU No. 10 Tahun 1998

3. Prinsip Kerahsiaan (Secrecy Principle)
Untuk prinsip kerahasiaan bank ini diatur pada Pasal 40 sampai dengan Pasal 47A Undang-Undang Nomor 10 Tahun 1998 tentang Perbankan. Dalam prinsip ini bank wajib merahasiakan keterangan mengenai nasabah penyimpan dan yang disimpannya. Dalam ketentuan kewajiban untuk merahasiakan itu bukan tanpa pengecualian, kewajiban untuk merahasiakan ini dikecualikan untuk kepentingan hal-hal seperti kepentingan pajak, penyelesaian utang piutang bank yang sudah diserahkan ke lelang atau panitia urusan piutang negara (UPLN/PUPN), untuk kepentingan pengadilan pidana, pengadilan perdata antara bank dengan nasabah dan dalam rangka tukar-menukar informasi antar bank. Pengertian rahasia bank di dalam Undang-Undang No. 10 Tahun 1998 menurut Pasal 1 angkat 28 adalah "segala sesuatu yang berhubungan dengan keterangan mengenai nasabah penyimpan dan simpanannya." Berkaitan dengan prinsip kerahasiaan bank ini, terdapat 2 (dua) teori yang dikenal pada teori rahasia bank yaitu:

a) Teori rahasia bank relatif

Bank diperbolehkan membuka rahasia nasabahnya bila untuk suatu kepentingan yang mendesak, misalnya kepentingan negara

b) Teori rahasia bank absolut

Bahwa bank berkewajiban untuk menyimpan rahasia nasabahnya yang hanya diketahui oleh bank karena kegiatan usahanya baik dalam keadaan apapun, biasa ataupun dalam keadaan luar biasa.

4. Prinsip Mengenal Nasabah (Know How Costumer Principle)

Untuk prinsip mengenal nasabah ini, diterapkan oleh pihak bank agar lebih mengenal dan mengetahui identitas setiap nasabah maupun calon nasabah, untuk memantau setiap kegiatan transaksi nasabah termasuk melaporkan setiap bentuk transaksi yang mencurigakan yang dilakukan oleh nasabah. Prinsip mengenal nasabah ini diatur dalam Peraturan Bank Indonesia yang selanjutnya disingkat 
menjadi PBI, yaitu PBI Nomor 3/10/PBI/2001 tentang Penerapan Prinsip Mengenal Nasabah. Tujuan dari adanya prinsip mengenal nasabah ini adalah untuk meningkatkan peran lembaga keuangan dengan berbagai bentuk kebijakan untuk kemudian menunjang praktik lembaga keuangan, menghindari dari setiap berbagai kemungkinan lembaga keuangan dijadikan tempat tindak kejahatan dan aktivitas ilegal yang dapat dilakukan oleh nasabah, serta untuk melindungi nama baik dan reputasi dari lembaga keuangan itu sendiri.

Dari penjelasan prinsip-prinsip diatas, terlihat bahwa bank dalam membangun kegiatan usahanya untuk menarik nasabah haruslah didasari dengan keempat dasar prinsip tersebut. Rasa percaya dari masyarakat dapat menjadi awal permulaan bagi bank untuk membangun hubungan antara nasabah dengan pihak bank, selain itu jika bank dapat memberikan keamanan dan jaminan bahwa dana yang disimpan oleh nasabah aman dan setiap data nasabah dijaga dengan aman dan tidak disalahgunakan, maka nasabah akan semakin menaruh kepercayaannya kepada bank, sehingga tidak menutup kemungkinan bahwa semakin banyak yang akan menabung di bank, dan menjadi nasabah disetiap produk yang dikeluarkan oleh bank.

Untuk fungsi dari sebuah perbankan dapat dilihat dalam ketentuan Pasal 3 Undang-Undang Nomor 10 Tahun 1998 tentang Perbankan yaitu "fungsi utama perbankan Indonesia adalah sebagai penghimpun dan penyalur dana masyarakat" Pasal ini mencerminkan fungsi dari suatu bank itu sendiri, yang berfungsi sebagai perantara pihak-pihak yang memiliki kelebihan dana dengan pihak pihak yang memerlukan dana. Fungsi Bank selain sebagai agent of development dalam kaitannya dengan pemberian kredit, bank juga bertindak sebagai agent of trust, yakni dalam kaitannya dengan pelayanan dan/atau jasa-jasa yang diberikan baik kepada perorangan maupun kelompok atau perusahaan. Oleh karena itu, bank sebagai sebuah lembaga keuangan yang mengelola dana-dana masyarakat, membutuhkan keahlian untuk mengelola usaha perbankan secara profesional, karena jika kepercayaan masyarakat kurang terhadap lembaga perbankan masyarakat pun akan berlomba menarik dana yang disimpan di bank, dampak yang lebih jauh bisa dilihat dari kegiatan perekonomian tidak dapat berjalan sebagaimana yang diharapkan. Terdapat tiga tugas yang dilakukan oleh lembaga perbankan: pertama, operasi perkreditan secara aktif, dalam hal ini bank menciptakan atau memberikan kredit kepada masyarakat; kedua, operasi perkreditan secara pasif, yang berarti bank menerima simpanan masyarakat; ketiga, bank sebagai perantara pemberi kredit.

Tujuan dari sebuah perbankan di Indonesia tercantum dalam Pasal 4 UndangUndang tentang Perbankan yang berbunyi : "Perbankan Indonesia bertujuan menunjang pelaksanaan pembangunan nasional dalam rangka meningkatkan pemerataan, pertumbuhan ekonomi dan stabilitas nasional kearah peningkatan kesejahteraan rakyat banyak." Wujud dari peningkatan kesejahteraan masyarakat antara lain melalui pemberian fasilitas kredit yang dapat dijangkau oleh masyarakat, sehingga lewat kredit yang diperoleh tersebut dapat digunakan dalam berbagai kebutuhan yang produktif. Namun untuk memberikan kredit ini harus memperhatikan prinsip kehatihatian.

Dalam Undang-Undang Perbankan tidak mengatur ketentuan tentang hubungan hukum antara bank dengan nasabah secara eksplisit. Menurut para ahli, bahwa hubungan hukum antara bank dengan nasabah berdasarkan atas suatu perjanjian yaitu kontrak. Menurut Try Widiyono, menyatakan bahwa hubungan antara bank dengan nasabah berdasarkan prinsip kepercayaan, dimana hubungan antara bank dengan nasabah terdapat formulir-formulir yang telah diisi oleh nasabah dan disetujui oleh bank, formulir-formulir tersebut berisi tentang permohonan atau perintah atau kuasa kepada bank. Dari kedua pendapat tersebut dapat ditarik kesimpulan bahwa yang menjadi landasan utama hubungan antara pihak bank dengan nasabah adalah prinsip kepercayaan yang dituangkan melalui kontrak atau perjanjian, pada umumnya bentuk perjanjian 
antara bank dan nasabah sudah dibuat dalam kontrak standar atau baku. Hal ini berarti, sesuai dengan hakikat kontrak, para pihak dalam hal ini bank dan nasabah mempunyai hak dan kewajiban dalam mengadakan hubungan hukum yang dimaksud.

Dalam perjanjian kartu kredit itu sendiri, terdapat tiga pihak yang terlibat dalam hubungan kartu kredit yaitu pemegang kartu sebagai pembeli, penerbit sebagai pembayar dan pengusaha dagang sebagai penjual. Berdasarkan perjanjian, pemegang kartu kredit membeli barang dan atau jasa dari penjual yang ditunjuk oleh penerbit, dengan pembayaran menggunakan kartu kredit, lalu pembayaran oleh pembeli kepada penjual dilakukan melalui penerbit. Sehingga, hubungan hukum antara pemegang kartu dengan penerbit kartu dalam kartu kredit lahir karena adanya perjanjian antara pemegang kartu kredit dengan penerbit kartu kredit. Hubungan hukum antara penerbit kartu dengan pemegang kartu ini didasari oleh perjanjian baku yang telah disediakan pada umumnya oleh pihak Bank. Hubungan kontraktual ini bersumber kepada Kitab Undang-Undang Hukum Perdata (KUHPerdata) yang didasarkan atas ketentuan Pasal 1338 ayat 1 KUHPerdata bahwa semua perjanjian yang dibuat secara sah berlaku sebagai Undang-Undang bagi para pihaknya. Hubugan hukum antara nasabah dengan pihak bank yang terjadi dalam kegiatan pembiayaan kartu kredit dibuat secara tertulis sebagai dokumen hukum yang menjadi dasar kepastian hukum. Dalam hubungan hukum ini terdapat dua bentuk perjanjian, yaitu : perjanjian penerbitan kartu kredit, dan perjanjian penggunaan kartu kredit. Perjanjian penerbitan kartu kredit adalah persetujuan antara bank/perusahaan pembiayaan sebagai penerbit dan pemegang kartu kredit sebagai pihak peminjam uang. Sifat dari perjanjian penerbitan kartu kredit ini adalah bilateral, karena hanya melibatkan dua pihak yaitu pihak bank sebagai penerbit kartu, dan nasabah sebagai pemegang kartu kredit. Perjanjian penerbitan kartu kredit ini menurut Munir Fuady, mirip dengan perjanjian kredit bank, di mana mata uang akan dibayar kembali secara mencicil pada karatu kredit dan akan dibayar kembali sekaligus pada waktu penagihan dalam kartu pembayaran tunai. Perjanjian penerbitan kartu kredit ini sebagai perjanjian pokok. Perjanjian penggunaan kartu kredit adalah persetujuan yang melibatkan pihak tiga pihak yaitu bank sebagai penerbit dan pembayar, pemegang kartu sebagai pembeli dan perusahaan dagang sebagai penjual. Perjanjian penggunaan kartu kredit bersifat segitiga karena melibatkan tiga pihak, perjanjian ini merupakan perjanjian pelengkap, dimana perjanjian baru terbentuk jika ada perjanjian pokok, konsekuensi dari perjanjian pelengkap ini adalah apabila perjanjian penerbitan kartu kredit antara penerbit kartu kredit dengan pemegang kartu kredit batal, maka perjanjian jual beli barang dan atau jasa yang dari semua dikaitkan dengan penggunaan kartu kredit antara pemegang kartu kredit dengan penjual akan batal juga. Perjanjian penerbitan kartu kredit dan perjanjian penggunaan kartu kredit merupakan dokumen hukum utama yang dibuat secara sah dengan memenuhi syaratsyarat sebagaimana telah ditetapkan dalam Pasal 1320 KUHPerdata. Akibat hukum perjanjian yang dibuat secara sah maka akan berlaku sebagai Undang-Undang bagi para pihak, yang dalam hal ini adalah bank, pemegang kartu kredit dan perusahaan dagang. Adapun konsekuensi yuridis selanjutnya adalah perjanjian tersebut harus dilaksanakan dengan itikad baik dan tidak dapat dibatalkan secara sepihak, perjanjian penerbitan kartu kredit dan perjanjian penggunaan kartu kredit tersebut berfungsi sebagai dokumen bukti yang sah bagi bank/perusahaan pembiayaan, pemegang kartu kredit dan perusahaan dagang. Sehingga hukum antara nasabah pemegang kartu dan bank sebagai pihak penerbit timbul karena adanya perjanjian yang mengikat kedua belah pihak. Dari sebuah perjanjian yang dibuat dan disepakati secara bersama-sama ini melahirkan sebuah hak dan kewajiban yang harus dipenuhi oleh para pihak yang ada dalam perjanjian tersebut. Hak dan kewajiban ini pun turut menimbulkan suatu tanggung jawab secara hukum terdapat kedua belah pihak. 


\section{B. Bentuk Tanggung Jawab dan Perlindungan Hukum dari Bank kepada Nasabah Pengguna Kartu Kredit}

Sebelum membahas bagaimana bentuk tanggung jawab dan perlindungan hukum suatu bank kepada nasabahnya, akan lebih baik untuk mengetahui apakah bank dapat dikategorikan sebagai subjek hukum dan diminta pertanggungjawabannya kah atau tidak? Dalam Hukum Perdata, terdapat dua macam subjek hukum, yaitu orang perorangan dan badan hukum, sebuah badan hukum dianggap sebagai suatu subjek hukum mandiri (persona stand in judicio). Badan hukum ini mempunyai pengurusnya sendiri dan kekayaan sendiri yang terpisah dari kekayaan pemiliknya sehingga badan hukum ini ikut serta dalam lalu-lintas hukum dengan perantara pengurusnya dan dapat digugat dan dapat juga menggugat di pengadilan. Di Indonesia, bentuk-bentuk perusahaan yang dikenal dan diakui sebagai badan hukum adalah Perseroan Terbatas (PT), Yayasan dan Koperasi. Karena pada umumnya bentuk sebuah bank di Indonesia berbentuk Perseroan Terbatas atau PT, sehingga membuat sebuah bank sebagai suatu subjek badan hukum mempunyai hak dan kewajiban yang timbul, dimana hak dan kewajiban tersebut harus dipenuh dan dapat dimintakan pertanggungjawabannya.

Hak-hak dari suatu perbankan menurut Lord Denning adalah sebagai berikut:

1. Menyediakan safe custody terhadap danadana pihak ketiga

2. Menyediakan rekening-rekening untuk pihak nasabah

3. Bertindak sebagai agen-agen untuk pihak tertentu

4. Membayar cek yang ditarik oleh nasabah

Selain itu, bank juga mempunyai hak untuk :

1. Mendapatkan provisi terhadap layanan jasa yang diberikan kepada nasabah

2. Menolak pembayaran apabila tidak memenuhi persyaratan yang telah disepakati bersama

3. Melelang agunan dalam hal nasabah tidak mampu melunasi kredit yang diberikan kepadanya sesuai dengan akad kredit yang telah ditandatangani kedua belah pihak
4. Pemutusan rekening nasabah

5. Mendapatkan buku cek, bilyet giro, buku tabungan, kartu kredit dalam hal terjadi penutupan rekening

Hak-hak dan tanggung jawab suatu bank juga dapat diperinci sebagai berikut:

1. Menerima cash dan membayar dokumentasi yang mesti dibayar oleh nasabah, seperti terhadap cek, pengiriman uang, bills of exchange dan lain-lain instrumen perbankan

2. Membayar kembali uang nasabah yang ditempatkan di bank tersebut apabila dimintakan oleh pihak nasabah

3. Meminjamkan uang kepada nasabah

4. Menjaga kerahasiaan account dari nasabah dalam hubungan dengan kerahasiaan bank, kecuali apabila ditentukan lain oleh peraturan perundang-undangan

5. Jika pihak nasabah mempunya dua rekening ada kewajiban moral bagi bank untuk membuat rekening tersebut terpisah satu sama lain

6. Jika rekening ditutup, bank harus mempunyai alasan yang reasonable untuk menutup rekening tersebut.

Pada Pasal 6 dan Pasal 7 UndangUndang Nomor 7 Tahun 1992 sebagaimana telah diubah menjadi Undang-Undang Nomor 10 Tahun 1999 mengatur tentang hak bank sebagai pelaku usaha. Untuk kewajiban yang harus dipenuhi oleh suatu bank dalam menjalankan kegiatan usahanya dan untuk menjaga kepercayaan nasabahnya, menurut Undang-Undang Perbankan adalah :

1. Bank wajib memelihara tingkat kesehatan bank sesuai dengan ketentuan kecukupan modal, kualitas, aset, kualitas manajemen, likuiditas, rentabilitas, solvabilitas dan aspek lain yang berhubungan dengan usaha bank dan wajib melakukan kegiatan usaha sesuai dengan prinsip kehati-hatian. (Pasal 29 Ayat 2 UU Perbankan)

2. Dalam memberikan kredit atau pembiayaan berdasarkan prinsip syariah dan melakukan kegiatan usaha lainnya, bank wajib menempuh cara-cara yang tidak merugikan bank dan kepentingan nasabah yang mempercayakan dananya kepada bank. (Pasal 29 Ayat 3 UU Perbankan) 
3. Untuk kepentingan nasabah, bank wajib menyediakan informasi mengenai kemungkinan timbulnya resiko kerugian seubungan dengan transaksi nasabah yang dilakukan melalui bank. (Pasal 29 Ayat 4 UU Perbankan)

4. Bank wajib menyampaikan kepada Bank Indonesia segala keterangan dan penjelasan mengenai usahanya menurut tata cara yang ditetapkan oleh Bank Indonesia. (Pasal 30 ayat 1 UU Perbankan)

5. Bank atas permintaan bank Indonesia, wajib memberikan kesempatan bagi pemeriksaan buku-buku dan berkasberkas yang ada padanya, serta wajib memberikan bantuan yang diperlukan dalam rangka memperoleh kebenaran dari segala keterangan, dokumen dan penjelasan yang dilaporkan oleh bank yang bersangkutan. (Pasal 30 Ayat 2 UU Perbankan)

6. Bank wajib menyampaikan kepada Bank Indonesia neraca dan perhitungan laba/rugi tahunan serta penjelasannya, serta laporan berkala lainnya, dalam waktu dan bentuk yang ditetapkan oleh Bank Indonesia. (Pasal 34 Ayat 1 UU Perbankan)

7. Neraca serca perhitungan laba/rugi tahunan sebagaimana dimaksud dalam ayat (1) wajib terlebih dahulu diaudit oleh akuntan publik. (Pasal 34 Ayat 2 UU Perbankan)

8. Bank wajib mengumumkan neraca dan perhitungan laba/rugi dalam waktu dan bentuk yang ditetapkan oleh Bank Indonesia. (Pasal 35 UU Perbankan)

9. Setiap bank wajib menjamin dana masyarakat yang disimpan pada bank yang bersangkutan. (Pasal 37b Ayat 1 UU Perbankan)

10. Bank wajib merahasiakan keterangan mengenai Nasabah penyimpan dan simpanannya, kecuali dalam hal sebagaimana dimaksud dalam Pasal 41 Pasal 44 A.

Tidak hanya bank saja yang memiliki hak dan kewajiban kepada nasabah, nasabah pun juga mempunyai hak dan kewajiban yang harus dipenuh kepada bank, kewajiban sebagai nasabah yaitu :

a. Mengisi dan menandatangani formulir yang telah disediakan oleh bank, sesuai dengan layanan jasa yang diinginkan oleh calon nasabah

b. Melengkapi persyaratan yang ditentukan oleh bank

c. Menyetor dana awal yang ditentukan oleh bank. dalam hal ini, dana awal tersebut cukup bervariasi tergantung dari jenis layanan jasa yang diinginkan

d. Membayar provisi yang ditentukan oleh bank

e. Menyerahkan buku cek/giro bilyet tabungan.

Selain itu, nasabah mempunyai hak untuk

a. Mendapatkan layanan jasa yang diberikan oleh bank, seperti fasilitas kartu anjungan tunai mandiri (ATM)

b. Mendapatkan laporan atas transaksi yang dilakukan melalui bank

c. Menuntut bank dalam hal terjadi pembocoran rahasia nasabah

d. Mendapatkan agunan kembali, bila kredit yang dipinjam telah lunas

e. Mendapat sisa uang pelelangan dalam hal agunan dijual untuk melunasi kredit yang tidak berbayar

Hal-hal diatas merupakan hak dan kewajiban pihak bank sebagai suatu perusahaan penyedia jasa, serta hak dan kewajiban nasabah bank sebagai pihak pengguna jasa. Jika didalam sebuah perjanjian kartu kredit, hak dan kewajiban Bank sebagai penerbit kartu kredit dan nasabah bank sebagai pemegang kartu adalah sebagai berikut :

1. Penerbit Kartu (issuer)

Hak sebagai penerbit kartu adalah :

a. Memperoleh pembayaran uang pangkal, uang tahunan, biaya administrasi, bunga dan denda dari pemegang kartu;

b. Memperoleh kembali pembayaran harga pembelian barang/jasa dari pemegang kartu;

c. Memperoleh discount (komisi) dari penjual atas tagihan yang dibayarkan secara langsung oleh penerbit; 
Kewajiban sebagai penerbit kartu adalah :

a. Memberikan kartu kredit kepada pemegang kartu;

b. Membayar lunas harga barang/jasa atas bukti transaksi yang disodorkan oleh penjual;

c. Memberitahukan segala sesuatu yang menyangkut tentang hak, kewajiban dan kemudahan-kemudahan pemegang kartu;

d. Memberitahu setiap tagihan dalam suatu periode tertentu biasanya setiap satu bulan sekali kepada pemegang kartu

2. Pemegang Kartu (Card Holder)

Hak sebagai pemegang kartu adalah :

a. Menggunakan kartu kredit untuk membeli barang/jasa dengan atau tanpa batas maksimum;

b. Menarik uang tunai melalui ATM tertentu dengan nomor kode pada bank penerbit atau bank lain sampai batas tertentu;

c. Memperoleh informasi mengenai segala sesuatu yang menyangkut tentang perkembangan kreditnya dan kemudahan-kemudahan lain dari penerbit.

Kewajiban sebagai pemegang kartu adalah :

a. Membayar uang pangkal, uang tahunan, biaya administrasi, bunga dan denda kepada penerbit;

b. Mematuhi batas maksimum pembayaran dengan menggunakan kartu kredit;

c. Menandatangani bukti transaksi yang disodorkan oleh penjual;

d. Membayar kembali harga pembelian sesui dengan tagihan penerbit.

Dengan adanya hak dan kewajiban, maka akan timbul tanggung jawab untuk memenuhi hak dan kewajiban tersebut, terlebih lagi jika hak dan kewajiban itu menyangkut kepada pihak lain. Tentunya jika tidak menjalankan hak dan kewajiban ini terdapat konsekuensi yang harus ditanggung oleh kedua belah pihak. Seperti yang sudah dijelaskan pada bab sebelumnya bahwa timbulnya tanggung jawab bank kepada nasabah dan begitu sebaliknya, karena ada hubungan hukum yang sah antara pihak bank dengan nasabah, dimana hubungan ini didasarkan atas kepercayaan dan kontraktual sehingga hubungan antara bank dengan nasabah menimbulkan dua sisi tanggung jawab. Karena adanya hubungan antara nasabah dengan bank ini, dan adanya hak, kewajiban serta tanggung jawab antara kedua belah pihak, tidak dapat dipungkiri bahwa memungkinkan untuk terjadinya perbuatanperbuatan melawan hukum ataupun perbuatan yang merugikan para pihak.

Jika kelalaian dan tindakan melawan hukum tersebut dilakukan oleh pihak bank baik itu pegawai maupun pengurus dalam melindungi nasabah nya dan merugikan pihak nasabah, maka bentuk tanggung jawab yang dapat dilakukan oleh Bank, jika dikaji melalui KUHPerdata, maka menurut Pasal 1367 KUHPerdata bahwa "Seseorang tidak hanya bertanggung jawab atas kerugian yang disebabkan perbuatannya sendiri, melainkan juga atas kerugian yang disebabkan perbuatan-perbuatan orangorang yang menjadi tanggungannya atau disebabkan barang-barang yang berada di bawah pengawasannya" selain Pasal 1367 KUHPerdata, dalam Peraturan Otoritas Jasa Keuangan No.1/POJK.07/2013 Pasal 29 juga menyatakan "Bahwa pelaku usaha jasa keuangan wajib bertanggungjawab atas kerugian konsumen yang timbul akibat kesalaan dan atau kelalaian, pengurus, pegawai pelaku usaha jasa keuangan dan/atau pihak ketiga yang bekerja untuk kepentingan pelaku usaha jasa keuangan." Bentuk tanggung jawab ini merupakan sebagai salah satu cara pihak bank untuk memberikan perlindungan kepada konsumen. Menurut Peraturan Otoritas Jasa Keuangan Nomor 1/POJK/07/2013 Pasal 2 menyebutkan bahwa bank wajib menjaga kerahasiaan dan keamanan data/informasi konsumen. Selain Pasal 2, Pasal 25 POJK ini juga menyatakan bahwa "Pelaku usaha jasa keuangan wajib menjaga keamanan simpanan, dana atau aset konsumen yang berada dalam tanggung jawab pelaku usaha jasa keuangan” Jika seperti kasus pembobolan dan bocornya data konsumen tersebut, maka bank dalam hal ini gagal untuk memberikan perlindungan kepada konsumen. Tidak hanya dalam POJK ini saja, 
didalam Undang-Undang Nomor 8 Tahun 1999 tentang Perlindungan konsumen pada Pasal 4 Undang-Undang ini menyebutkan bahwa konsumen berhak secara khusus untuk mendapatkan :

1. Hak atas kenyamanan, keamanan dan keselamatan dalam mengkonsumsi barang dan/atau jasa

2. Hak untuk memilih barang dan/atau jasa serta mendapatkan barang dan/atau jasa tersebut sesuai dengan nilai tukar dan kondisi serta jaminan yang dijanjikan

3. Hak atas informasi yang benar, jelas dan jujur mengenai kondisi dan jaminan barang dan/atau jasa

4. Hak untuk didengar pendapat dan keluhannya atas barang dan/atau jasa yang digunakan

5. Hak untuk mendapatkan advokasi, perlindungan dan upaya penyelesaian sengketa perlindungan konsumen secara patut.

6. Hak untuk mendapatkan pembinaan dan pendidikan konsumen

7. Hak untuk diperlakukan atau dilayani secara benar dan jujur serta tidak diskriminatif

8. Hak untuk mendapatkan kompensasi, ganti rugi dan/atau penggantian apabila barang dan/atau jasa yang diterima tidak sesuai dengan perjanjian atau tidak sebagaimana mestinya

9. Hak-hak yang diatur dalam ketentuan peraturan perundang-undangan lainnya

Sehingga, bank dapat bertanggung jawab kepada nasabah yang dirugikan dengan cara seperti berikut :

1. Pelaku usaha jasa keuangan wajib memiliki dan melaksanakan mekanisme pelayanan dan penyelesaian pengaduan bagi konsumen;

2. Pelaku usaha jasa keuangan wajib segea menindaklanjuti dan menyelesaikan pengaduan paling lambat 20 hari kerja setelah penerimaan pengaduan

3. Pelaku usaha yang telah menerima aduan terhadap konsumen wajib melakukan pemeriksaan internal atas pengaduan secara kompeten, benar, dan objektif. Selain itu melakukan analisis untuk memastikan kebenaran pengaduan tersebut dan menyampaikan pernyataan maaf dan menawarkan ganti rugi atau perbaikan produk dan atau layanan jika pengaduan konsumen benar.

Jika tidak terjadi kesepakatan maka nasabah mempuai hak untuk dapat melakukan penyelesaian sengket di luar pengadilan atau melalui pengadilan. Selain itu, Otoritas Jasa Keuangan atau OJK juga memberikan fasilitas untuk pengaduan konsumen dan penyelesaian sengketa. Namun pemberian fasilitas ini hanya diberikan kepada konsumen tertentu saja yaitu konsumen yang mengalami kerugian finansial paling banyak Rp.500.000.000,00 dan untuk pelaku usaha yang mengalami kerugian finansial banyak Rp. 750.000.000,00.

\section{KESIMPULAN}

Dari penjabaran diatas, sehingga dapat ditarik kesimpulan bahwa :

1. Hubungan yang timbul antara bank dengan nasabah adalah hubungan kontraktual yang dilandasi dengan prinsip kepercayaan dari nasabah kepada bank untuk menyimpan dan menggunakan produk di bidang jasa keuangan yang ditawarkan oleh pihak bank kepada nasabah. Dari prinsip kepercayaan ini, pihak bank menuangkan kedalam bentuk kontrak yang biasanya pihak nasabah isi berupa formulir permintaan data dan tanda tangan syarat dan kondisi untuk dapat menjadi bagian dari nasabah suatu perbankan. Dengan adanya kontrak ini yang merupakan hasil kesepakatan antara dua pihak, melahirkan hak dan kewajiban yang harus dipenuhi oleh satu sama lain. Selain itu, hak dan kewajiban yang tidak dipenuhi, maka akan menjadi tanggungjawab masing-masing pihak. Bank sebagai lembaga yang bergerak dibidang jasa keuangan, tentunya memberikan perlindungan keamanan kepada nasabah, sehingga baik menurut undang-undang maupun perjanjian antara nasabah dengan bank, jika terjadi sesuatu hal yang merupakan kelalaian pihak bank dalam melindungi nasabahnya, maka pihak bank akan bertanggungjawab. Tanggung jawab ini kembali lagi lahir 
karena adanya kesepakatan antara dua pihak.

2. Jika terjadinya suatu tindakan yang di karenakan kelalaian dan kelemahan dari pihak bank, yang pada akhirnya merugikan konsumen, maka bentuk tanggung jawab yang dapat dilakukan oleh bank adalah memberikan ganti rugi kepada konsumen setelah melakukan investigasi lebih lanjut terhadap laporan atau pengaduan yang dilaporkan oleh konsumen, selain itu, pihak bank wajib meminta maaf dan menawarkan untuk memberikan produk atau jasa baru kepada konsumen. Hal ini diatur didalam Peraturan Otoritas Jasa Keuangan No. 1/POJK.07/2013 tentang Perlindungan Konsumen di bidang Jasa keuangan.

\section{SARAN}

Bank dalam menjalankan kegiatan usahanya harus dapat lebih teliti dan melakukan pengawasan yang lebih ketat lagi serta telah memikirkan dan menyiapkan setiap kemungkinan yang akan terjadi di kemudian hari. Mengingat dengan perkembangan teknologi yang begitu pesat, maka kelalaian terhadap pengawasan keamanan perbankan akan menjadi sebuah bom atom untuk bank itu sendiri. Peningkatan sistem keamana harus dilakukan secara terus menerus, dan jika perlu dilakukan secara berkala, pihak bank dapat melakukan doube-check terhadpa sistem keamanan yang digunakan, dengan begini konsumen pun akan lebih merasa aman untuk menggunakan jasa-jasa dan produk yang ditawarkan oleh pihak bank.

\section{DAFTAR PUSTAKA}

\section{Buku}

Djumhana, Mohammad.(2000). Hukum Perbankan di Indonesia. Bandung: Citra Aditya Bhakti.

Fuady,Munir. (1995). Hukum Tentang Pembiayaan dalam Teori dan Praktik (Leasing, Factoring, Modal Ventura, Pembiayaan Konsumen, Kartu Kredit). Bandung: Citra Aditya Bakti.

Fuady,Munir.(2003). Hukum Perbankan Modern. Bandung:Citra Aditya Bakti.

Hermansyah,(2008). Hukum Perbankan Nasional, Edisi Kedua. Jakarta:

Kencana
Sembiring,Sentosa.(2012). Hukum Perbankan Edisi Revisi. Bandung: CV Mandar Maju.

Simonangkir, O.P. (2004). Pengantar Lembaga Keuangan Bank dan Nonbank, Cetakan Kedua. Jakarta: Ghalia Indonesia

Sunaryo.(2008). Hukum Lembaga pembiayaan. Jakarta: Sinar Grafika

Jurnal dan E-book

Neni Sri Imaniyati, "Pencucian Uang ( Money Londering) dalam Perspektif Hukum Perbankan dan Hukum Islam", Mimbar, UNISBA, Bandung, Vo. XXI No. 1 Januari-Maret 2005

E-books Investasi Bank dan Lembaga Keuangan

https://books.google.co.id/books?id=x7f ADgAAQBAJ\&printsec $=$ frontcover\&hl $=\mathrm{id} \# \mathrm{v}=$ onepage $\& \mathrm{q} \& \mathrm{f}=$ false

\section{Peraturan Perundang-Undangan}

Kitab Undang-Undang Hukum Perdata

Undang-Undang Nomor 10 Tahun 1999 tentang Perbankan

Undang-Undang Nomor 8 Tahun 1999 tentang Perlindungan Konsumen

Undang-Undang Nomor 21 Tahun 2011 tentang Otoritas Jasa Keuangan

Peraturan Otoritas Jasa Keuangan Nomor 1/POJK.07/2013 tentang Perlindungan Konsumen di Bidang Jasa Keuangan 